Article

\title{
Butyrolactone-I from Coral-Derived Fungus Aspergillus terreus Attenuates Neuro-Inflammatory Response via Suppression of NF-KB Pathway in BV-2 Cells
}

\author{
Yuan Yuan Zhang ${ }^{1,+}$, Yi Zhang ${ }^{1,2,+}$, Yuan-Bei Yao ${ }^{1}$, Xiao-Ling Lei ${ }^{1, *}$ and Zhong-Ji Qian ${ }^{2,3, *}$ (D) \\ 1 College of Food Science and Technology, Guangdong Ocean University, Zhanjiang 524088, China; \\ zyyla92@126.com (Y.Y.Z.); hubeizhangyi@163.com (Y.Z.); 13286999640@163.com (Y.-B.Y.) \\ 2 Shenzhen Institute of Guangdong Ocean University, Shenzhen 518108, China \\ 3 College of Chemistry and Environment, Guangdong Ocean University, Zhanjiang 524088, China \\ * Correspondence: leixl-19@126.com (X.-L.L.); zjqian78@163.com (Z.-J.Q.) \\ + These authors contributed equally to this work.
}

Received: 4 May 2018; Accepted: 6 June 2018; Published: 7 June 2018

\begin{abstract}
Butyrolactone-I (ZB5-1) from the coral-derived fungus Aspergillus terreus was investigated in this study to estimate its anti-neuroinflammatory effects on lipopolysaccharide (LPS)-induced BV-2 microglia cells. MTT assay indicated that ZB5-1 in tested concentrations had no cytotoxicity on BV-2 cells, and significantly reduced the production of nitric oxide (NO), measured using Griess reagent, and interleukin-1 beta (IL-1 $\beta$ ), detected by enzyme-linked immunosorbent assay (ELISA). ZB5-1 also down-regulated the expression of inducible nitric oxide synthase (iNOS) and cyclooxygenase-2 (COX-2) in a dose-dependent manner by Western blot analysis. Moreover, the effect of ZB5-1 on the nuclear factor- $\mathrm{KB}(\mathrm{NF}-\mathrm{kB})$ signaling pathway was studied via the expression of phosphorylation of NF- $\kappa B$ p 65 and inhibitor of NF- $\kappa B(I \kappa B)$, and the nuclear translocation of NF- $k B$ p65 respectively. The results showed that ZB5-1 could inhibit the phosphorylation of p65 and IKB. Furthermore, molecular docking study suggested that ZB5-1 bound at the active sites of NF- $\kappa$ B to prevent its translocation to the nucleus. Therefore, we suggest ZB5-1 has a potential to reduce the anti-inflammatory response in LPS-induced BV-2 cells.
\end{abstract}

Keywords: butyrolactone-I; Aspergillus terreus; microglia; neuro-inflammation

\section{Introduction}

Microglia cells are ubiquitously distributed in the central nervous system (CNS) [1], functioning as the brain's resident macrophages to maintain brain homeostasis and protect the brain from infections and stimuli [2]. However, over-activation of microglia cells can release overproduction of pro-inflammatory cytokines, reactive oxygen species (ROS), and nitric oxide (NO), which can cause neuro-inflammation, a chief culprit of neurodegenerative diseases [3]. Therefore, for the sake of the development of therapeutic agents for neurodegenerative diseases, the exploration and identification of compounds that can suppress microglia cell activation has become a key process [4].

Up to now, it is estimated that nearly 100,000 fungal species have been discovered. Due to the species' diversity and the innovation of chemical, biological, and genetic approaches, fungi still represent the richest source of new metabolites. Additionally, an increasing number of endophytic and marine-derived fungi have been studied in recent years [5]. Such fungi provide a silver lining for new natural products screening, however, many potentials still need to be discovered [6]. The filamentous ascomycete fungus Aspergillus terreus is widely present in both marine and terrestrial 
creatures [7]. It is famous for its two valuable metabolites: Lovastatin and itaconic acid. The former is a cholesterol-lowering drug, while the latter is widely used in polymer manufacturing [8]. In addition, many researches have been conducted to explore and identify more lead compounds derived from $A$. terreus. In terms of structural or biogenetic types, those compounds are classified into polysaccharide [9], peptide [10,11], terrain [12,13], butyrolactone [12,14], meroterpenoids $[15,16]$, and other compounds with novel and complex structures.

Butyrolactone-I (ZB5-1) was obtained from A. terreus XWC21-10, an endophytic fungus isolated from Puko Shore coral (Porites pukoensis) in Xuwen (Guangdong, China). As a scleractinian coral, Porites account for $57 \%$ of total species in the Xuwen coral conservation area. At present, a few researches focus on P. pukoensis. One study isolated 23 fungal strains from P. pukoensis. These strains belonged to 10 genera, of which Aspergillus sp. occupied 30.4\%. In addition, the fermentation supernatant and mycelia of these fungi presented antibacterial activities [17]. Previous studies discovered and tested the anti-inflammatory effects of $A$. terreus derived compounds, such as butenolide derivatives [18,19] and meroterpenoids [20]. A butyrolactone I analogue, asperteretal A, significantly decreased the NO production in RAW264.7 cells [19]. Recently, Liu et al. [18] reported that butyrolactone I exhibited the inhibitory effect on NO, which is close to indomethacin.

Based on these results, in order to determine the molecular mechanism underlying the anti-inflammatory of ZB5-1, the present study estimated the anti-neuroinflammatory effects of ZB5-1 in BV-2 cells by in vitro experiment and molecular docking.

\section{Results}

\subsection{Identification of ZB5-1}

Butyrolactone-I was obtained as a yellowish oil by repeated column chromatography of the fermentation extract of marine fungal strain A. terreus XWC21-10. Its NMR and specific optical rotation data are listed as following and compared with a previous report [21].

${ }^{1} \mathrm{H}$ NMR $\left(\mathrm{CD}_{3} \mathrm{OD}, 700 \mathrm{MHz}\right): \delta_{\mathrm{H}} 7.59\left(\mathrm{H}-2^{\prime}\right.$ and $\left.\mathrm{H}-6^{\prime}, \mathrm{d}, 8.4\right), 6.87\left(\mathrm{H}-3^{\prime}\right.$ and $\left.\mathrm{H}-5^{\prime}, \mathrm{d}, 9.1\right)$, 6.54 (H-6", dd, 8.1, 2.1), 6.50 (H-5", d, 8.4), 6.41 (H-2", d, 2.1), 5.07 (H-8", m), 3.78 (H-7, s), 3.43 (H-5, d, 14.0), 3.08 (H-7"', m), 1.67 (H-10", s), 1.57 (H-11", s). ${ }^{13} \mathrm{C}-\mathrm{NMR}$ NMR $\left(\mathrm{CD}_{3} \mathrm{OD}, 175 \mathrm{MHz}\right)$ : $\delta_{\mathrm{C}} 171.41$ (C-6), 170.11 (C-1), 159.13 (C-4'), 154.88 (C-4"), 139.46 (C-2), 132.78 (C-9"), 132.19 (C-2"), $130.19\left(\mathrm{C}-2^{\prime}\right.$ and C-6'), 129.56 (C-3"), 129.01 (C-3), 128.23 (C-6"), 124.85 (C-1"), $123.36\left(\mathrm{C}-8^{\prime \prime}\right)$, $122.94\left(\mathrm{C}-1^{\prime}\right), 116.41\left(\mathrm{C}-3^{\prime}\right.$ and $\left.\mathrm{C}-5^{\prime}\right), 114.83\left(\mathrm{C}-5^{\prime \prime}\right), 86.59$ (C-4), 53.64 (C-7), 39.41 (C-5), 28.48 (C-7"), $25.75\left(\mathrm{C}-10^{\prime \prime}\right), 17.56\left(\mathrm{C}-11^{\prime \prime}\right)$ (Figure 1). $[\alpha]_{\mathrm{D}}^{20}+108.85^{\circ}(\mathrm{c} 0.2, \mathrm{MeOH})$.

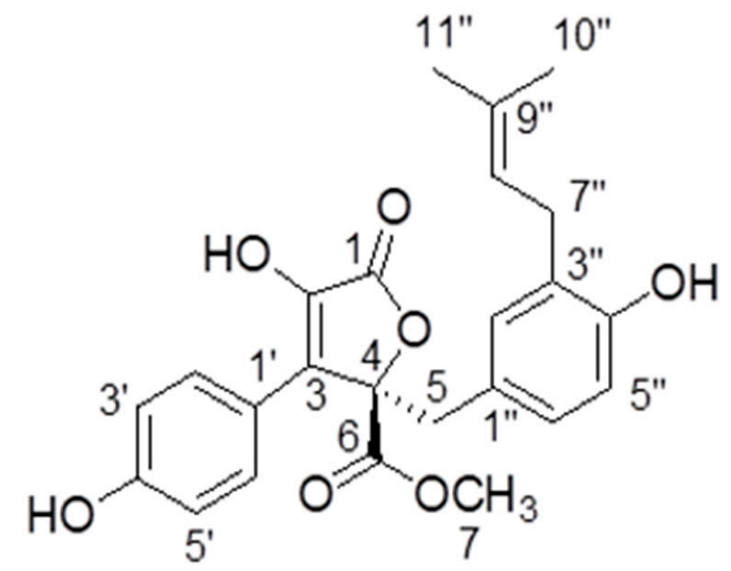

Figure 1. The structure of butyrolactone-I. 


\subsection{Effect of ZB5-1 on BV-2 Cell Viability}

The effect of ZB5-1 on BV-2 cell viability was measured by MTT assay. BV-2 cells were treated with different concentrations of ZB5-1 (10, 20, 50, and $100 \mu \mathrm{M})$. As shown in Figure 2, in the tested concentrations, ZB5-1 had no cytotoxicity on BV-2 cells. Therefore, concentrations of 10, 20, 50, and $100 \mu \mathrm{M}$ of ZB5-1 were used for the remainder of the study.

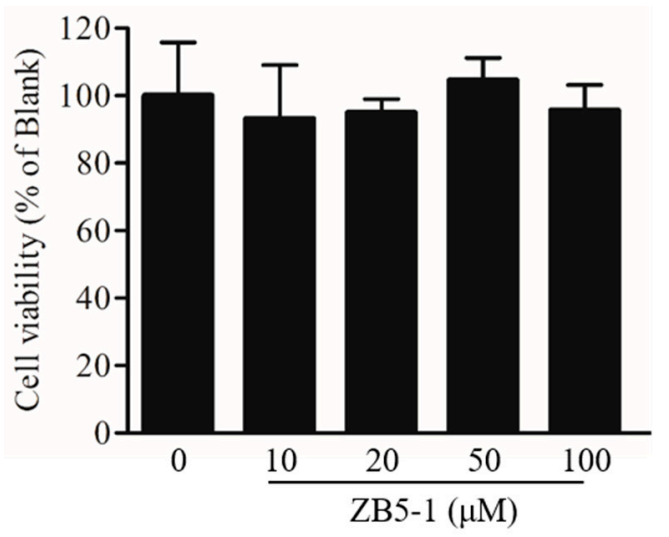

Figure 2. Effect of butyrolactone-I (ZB5-1) on the viability of BV-2 cells. The cells were treated with ZB5-1 (10, 20, 50, and $100 \mu \mathrm{M})$ for $24 \mathrm{~h}$. Cell viability was measured using MTT assay.

\subsection{Effect of ZB5-1 on NO Production in BV-2 Cells}

Griess reagent reaction was used to assess the level of NO of BV-2 cells treated with and without lipopolysaccharide (LPS) and ZB5-1. Figure 3 presented the experimental data of NO production. In resting state, BV-2 produced a small amount of NO. Once activated, the production of NO was reached at about $50 \mu \mathrm{M}$, a significant difference when compared with the resting state. When the cells were pre-treated with increasing concentrations of ZB5-1, the levels of NO were decreased. These results indicated that ZB5-1 could have a potential anti-inflammatory effect.

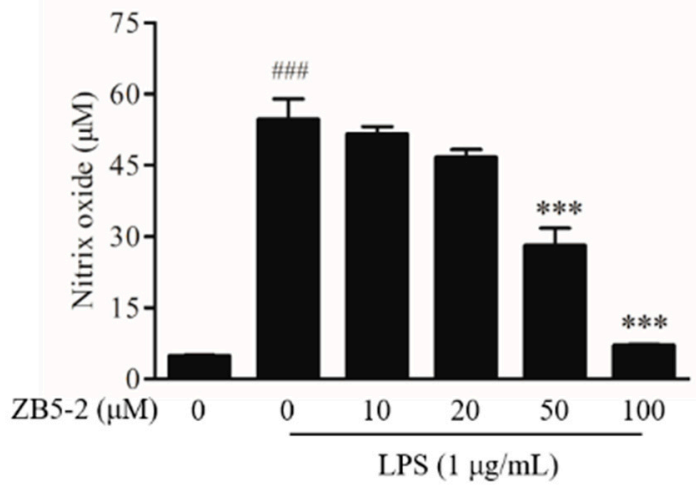

Figure 3. Inhibitory effect of ZB5-1 on nitric oxide (NO) production of BV-2 cells. The cells were pre-treated with various concentration of ZB5-1 $(10,20,50,100 \mu \mathrm{M})$ for $1 \mathrm{~h}$, and then stimulated by lipopolysaccharide (LPS) $(1 \mu \mathrm{g} / \mathrm{mL})$ for another $24 \mathrm{~h}$. The production of NO was measured using Griess reagent reaction. The results were expressed as the mean $\pm \operatorname{SD}(n=3)$. \#\#\# $p<0.001$ compared with Blank; ${ }^{* * *} p<0.001$ compared with Control.

\subsection{Effect of ZB5-1 on the Expression of iNOS and COX-2 in BV-2 Cells}

To investigate the inhibitory effect of ZB5-1 on the protein expression of inflammatory enzymes nitric oxide synthase (iNOS) and cyclooxygenase-2 (COX-2), the cells were pretreated with the indicated concentrations of ZB5-1 (10, 50, and $100 \mu \mathrm{M})$ before stimulated with LPS $(1 \mu \mathrm{g} / \mathrm{mL})$. As shown in 
Figure 4, ZB5-1 treatment decreased the levels of iNOS and COX-2. In particular, iNOS seemed to be more sensitive than COX-2 in BV-2 cells.

A
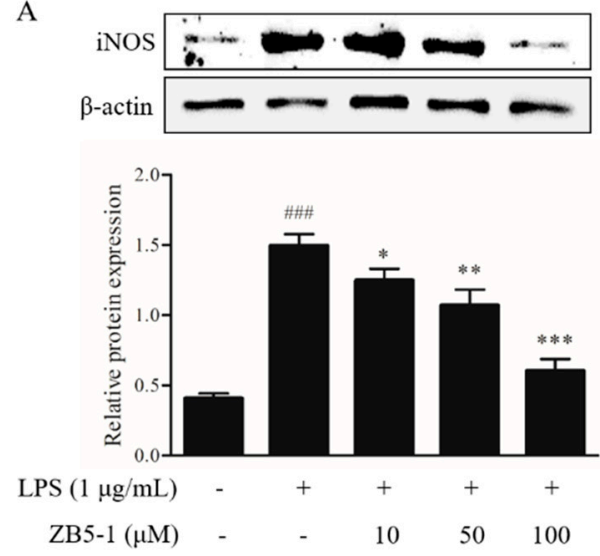

$\mathrm{B}$
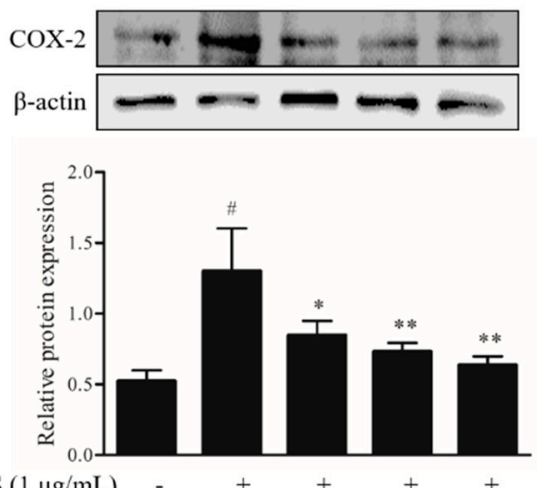

LPS $(1 \mu \mathrm{g} / \mathrm{mL})$

ZB5-1 $(\mu \mathrm{M}) \quad-\quad-\quad 10 \quad 50 \quad 100$

Figure 4. Inhibitory effect of ZB5-1 on protein expression of nitric oxide synthase (iNOS) (A) and cyclooxygenase-2 (COX-2) (B) of BV-2 cells. The cells were pre-treated with various concentration of ZB5-1 $(10,50,100 \mu \mathrm{M})$ for $1 \mathrm{~h}$, and then stimulated by LPS $(1 \mu \mathrm{g} / \mathrm{mL})$ for another $24 \mathrm{~h}$. Expression of iNOS and COX-2 were determined by Western blot. The results were expressed as the mean \pm SD $(n=3)$. \#\#\# $p<0.001$, \# $p<0.05$ compared with Blank; ${ }^{* * *} p<0.001,{ }^{* *} p<0.01,{ }^{*} p<0.05$ compared with Control.

\subsection{Effect of ZB5-1 on IL-1 $\beta$ Production in BV-2 Cells}

To investigate the inhibitory effect of ZB5-1 on interleukin-1 beta (IL-1 $\beta$ ), the cells were treated with LPS in the absence or presence of ZB5-1, and the levels were measured by enzyme-linked immunosorbent assay (ELISA). As shown in Figure 5, compared with unstimulated cells, the levels of IL-1 $\beta$ were increased in the culture media of LPS-induced cells, which were reduced by ZB5-1 in a dose-dependent manner.

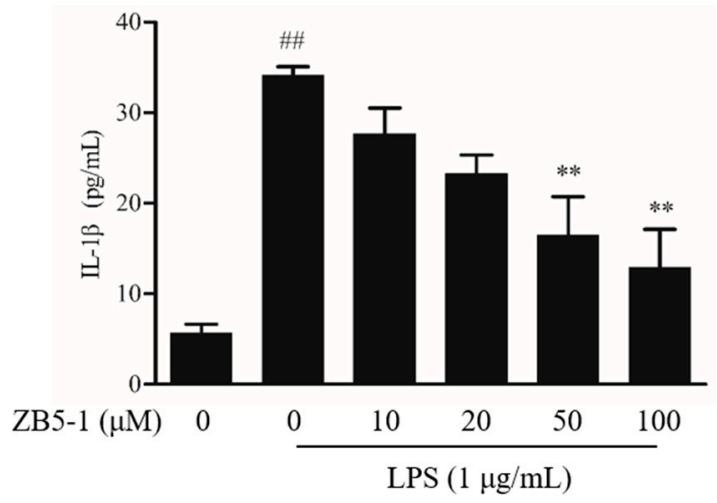

Figure 5. Inhibitory effect of ZB5-1 on interleukin-1 beta (IL-1 $\beta$ ) level of BV-2 cells. The cells were pre-treated with various concentration of ZB5-1 (10, 20, 50, and $100 \mu \mathrm{M})$ for $1 \mathrm{~h}$, and then stimulated by LPS $(1 \mu \mathrm{g} / \mathrm{mL})$ for another $24 \mathrm{~h}$. The levels of IL-1 $\beta$ was determined by ELISA. The results were expressed as the mean $\pm \mathrm{SD}(n=3)$. \#\# $p<0.01$ compared with Blank; ${ }^{* *} p<0.01$ compared with Control.

\subsection{Effect of ZB5-1 on NF- $\kappa B$ Phosphorylation of BV-2 Cells}

To investigate whether ZB5-1 inhibits the nuclear factor- $\mathrm{KB}$ (NF- $\mathrm{kB}$ ) signaling pathway, the phosphorylation of NF- $\kappa B$ p 65 and $I \kappa B \alpha$ were measured. As shown in Figure 6, phosphorylation of NF- $\kappa B$ p 65 and I $\mathrm{B} \alpha$ were dramatically increased when the cells were exposed to the LPS, however, they were down-regulated when the cells were pre-treated with ZB5-1. 

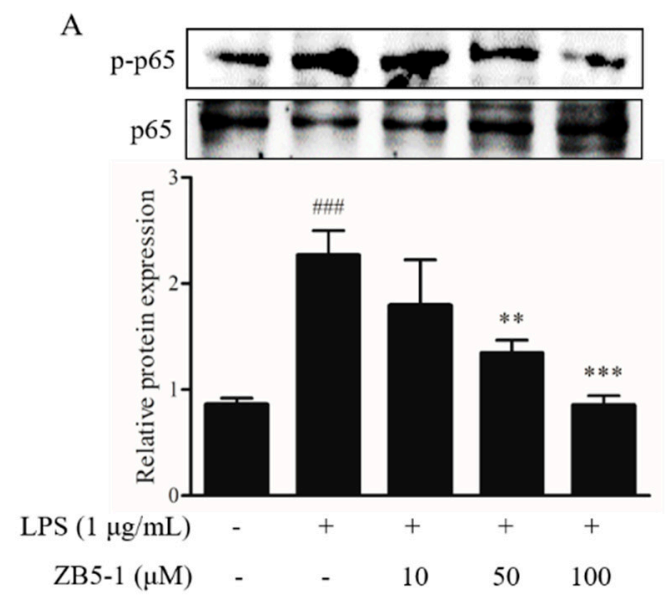

B
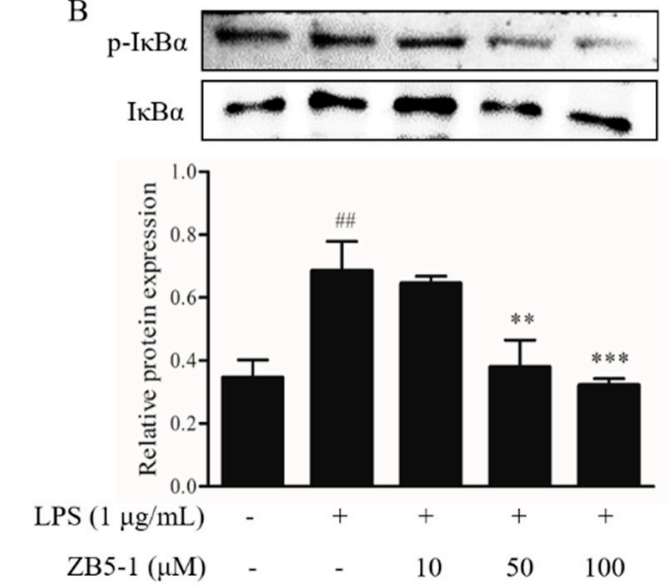

LPS $(1 \mu \mathrm{g} / \mathrm{mL})$

ZB5-1 $(\mu \mathrm{M})$

Figure 6. Inhibitory effect of ZB5-1 on the phosphorylation of NF- $\kappa B$ p65 (A) and I $\kappa$ B $\alpha(\mathbf{B})$ of BV-2 cells. The cells were pre-treated with various concentrations of ZB5-1 (10, 50, and $100 \mu \mathrm{M})$ for $1 \mathrm{~h}$, and then stimulated by LPS $(1 \mu \mathrm{g} / \mathrm{mL})$ for another $24 \mathrm{~h}$. The expression of $\mathrm{p}$-I $\kappa \mathrm{B} \alpha$ and p-p65 were determined by Western blot analysis. The results were expressed as the mean $\pm \operatorname{SD}(n=3)$. \#\#\# $p<0.001, \# \# p<0.01$ compared with Blank; ${ }^{* * *} p<0.001$, $^{* *} p<0.01$ compared with Control.

\subsection{Effect of ZB5-1 on NF- $\kappa B$ Translocation in BV-2 Cells}

The immunocytochemistry was availed to observe the location of a NF- $\mathrm{BB}$ p65 subunit in BV-2 cells. The nucleus was stained with DAPI, shown in Figure 7 in blue, while the p65 protein was incubated by an anti-NF- $\mathrm{kB}$ p 65 primary antibody and stained by DyLight 488 AffiniPure goat anti-rabbit IgG secondary antibody, shown in Figure 7 in green. Figure 7 shows the location of the NF- $k B$ p65 subunit. In the blank group, the p65 protein existed outside the nucleus with weak immunofluorescence. However, when the cells were exposed to LPS, the immunofluorescence became brighter than in the blank group and approached the nucleus, which meant LPS stimulation induced the translocation of p65 from cytoplasm to nucleus. The ZB5-1 exposure $(100 \mu \mathrm{M})$ decreased the translocation.

A

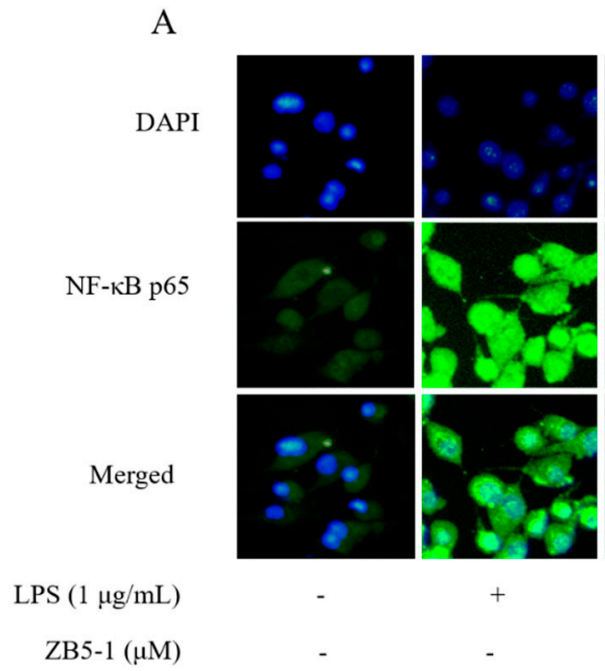

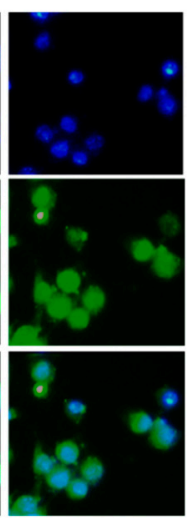

100
B

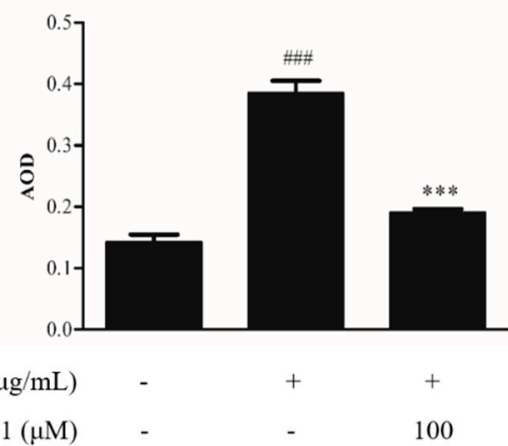

Figure 7. The effect of ZB5-1 on translocation of NF- $\mathrm{kB}$ p65 in BV-2 cells. The cells were pre-treated with $100 \mu \mathrm{M}$ ZB5-1 for $1 \mathrm{~h}$, and then stimulated by LPS $(1 \mu \mathrm{g} / \mathrm{mL})$ for another $24 \mathrm{~h}$. Nuclear translocation of NF- $\mathrm{B}$ p 65 was monitored by an overlay of blue DAPI staining with green p65 immunofluorescence (A). The average optical density (AOD) of fluorescence was measured by Image J and the results were expressed as the mean $\pm \mathrm{SD}(n=3)$. \#\#\# $p<0.001$, compared with Blank; ${ }^{* * *} p<0.001$, compared with Control (B). 


\subsection{Docking of ZB5-1 with NF- $\mathrm{B} B$ and COX-2}

To investigate the molecular mechanism for the binding of ZB5-1 and NF- $\mathrm{KB}$ along with COX-2, docking analysis of ZB5-1 within the NF- $\mathrm{kB}$ and COX-2 active site was performed using Discovery Studio (Figure 8). The obtained docking results showed that the docked pose of ZB5-1 with NF-kB has CDOCKER energy of $-110.64 \mathrm{kcal} / \mathrm{mol}$ and CDOCKER interaction energy of $-10.78 \mathrm{kcal} / \mathrm{mol}$. ZB5-1 formed two hydrogen bonds with NF-kB. One of the hydrogen bonds is formed with ASP 136 with a $4.3 \AA$ distance H-bond; the other hydrogen bond is formed with GLY 134 with a distance of $4.4 \AA$. In addition, the docked pose of ZB5- 1 with NF- $\mathrm{KB}$ has CDOCKER energy of $-0.38 \mathrm{kcal} / \mathrm{mol}$ and CDOCKER interaction energy of $43.40 \mathrm{kcal} / \mathrm{mol}$, and a phenolic group formed one hydrogen bond with COX-2 at TRP 373 with a distance of 6.1 A. Along with H-bonding, ZB5-1 established electrostatic interaction, i.e., van der Waals energies, with NF-kB and COX-2.

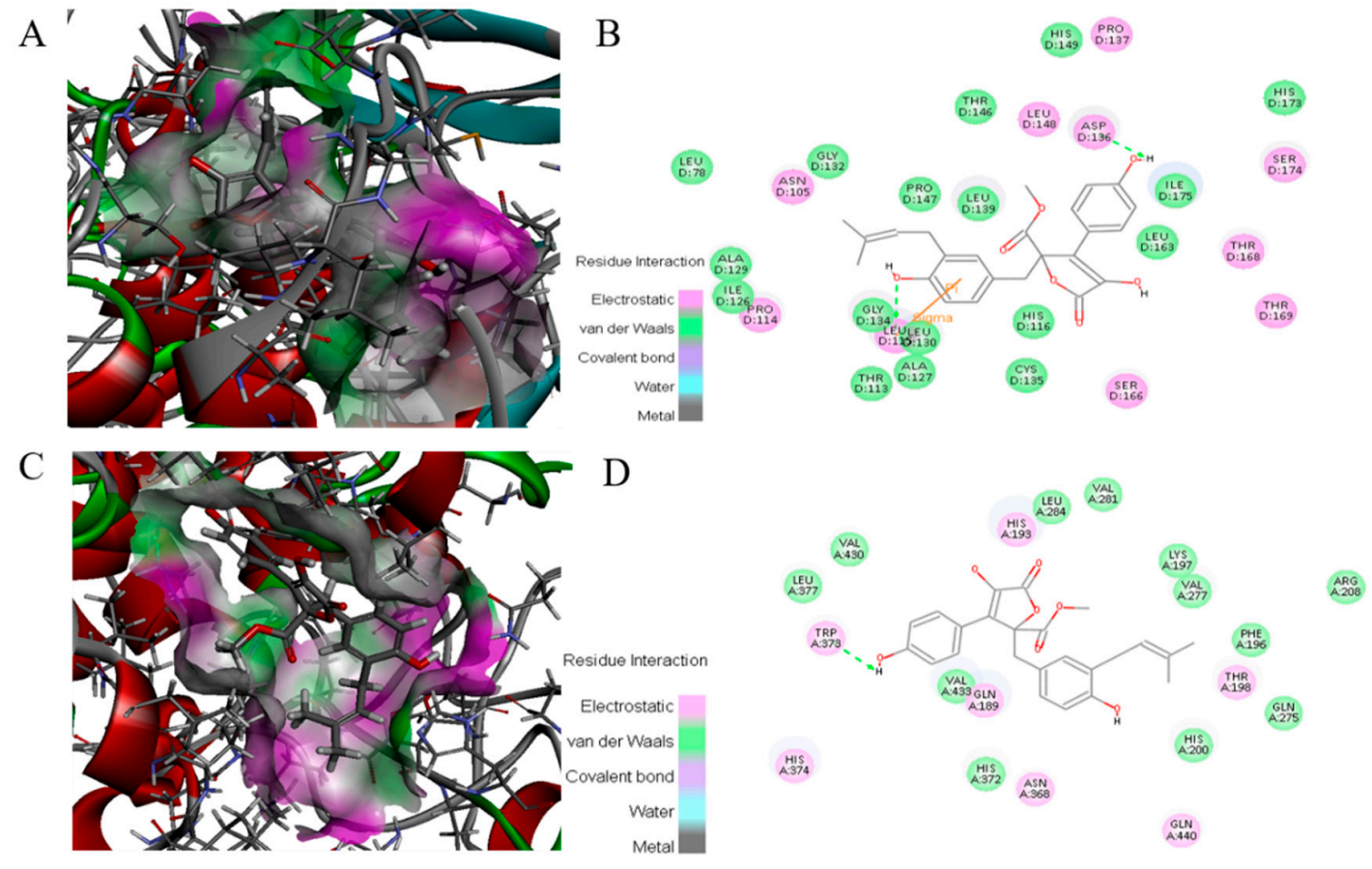

Figure 8. Binding mode of ZB5-1 into the NF- $\mathrm{BB}$ p65 (A) and 2-D depiction of the binding mode of ZB5-1 showing interactions formed with important residues. Hydrogen bonds formed with GLY 134 and ASP 136 (green arrow) (B). Binding mode of ZB5-1 into the COX-2 (C) and 2-D depiction of the binding mode of ZB5-1 showing interactions formed with important residues. Hydrogen bonds formed with TRP 373 (green arrow) (D).

\section{Discussion}

The Aspergillus genus is a rich source of butyrolactone derivatives, which are formed by a 5-membered lactone ring and two benzene rings [22]. Butyrolactone I was firstly reported in 1977, isolated from A. terreus [23]. Previous studies indicated that butyrolactone I has various activities, including anti-proliferative activity against human lung and prostatic cancer cell lines. More importantly, it can inhibit cyclin-dependent kinases (CDKs), particularly CDK1 and CDK2, both of which participate in mammalian cell progression from G1 to $S$ phase and from G2 phase to $M$ phase respectively [24]. For example, butyrolactone I can induce neuronal differentiation by inhibiting the Neuro 2a cell cycle progression [25], and can also reduce the apoptosis of X-ray and Doxorubicin-induced DLD1 (p21+/+) human colorectal carcinoma cells [26]. In this study, we estimated the anti-neuroinflammatory effect on an LPS-stimulated BV-2 microglia cell. 
Microglia cells can exert neuroprotective and neurotoxic functions in the brain. Activated by stimuli (e.g., LPS), they release pro-inflammatory factors such as $\mathrm{NO}, \mathrm{PGE}_{2}$, chemokines, and cytokines [27], which cause neuronal death, and IL-6, which can up-regulate amyloid precursor protein synthesis and processing. These processes are considered hallmarks of neuro-inflammation involved in the pathological process of neurodegenerative diseases [28]. Therefore, reduction of microglial cell activation is conducive to prevent or treat neurodegenerative diseases [29].

NO is a short-life, ubiquitous molecular mediator, regulating a wide range of physiologic functions from neurotransmission, gastric motility, wound healing, mitochondrial respiration, apoptosis, and inflammation [30]. It has been well-documented that NO is produced from L-arginine catalyzed by a class of nitric oxide synthases (NOS), namely neuronal NOS (nNOS or NOS1), endothelial NOS (eNOS or NOS3), and inducible NOS (iNOS or NOS2) [31]. According to its origin and production, NO exerts bifacial influences on physiological processes. Low amounts of NO derived from eNOS and nNOS is beneficial, whereas prodigious amounts of NO synthesized from iNOS are observed in different experimental models of inflammation [32,33]. Several studies suggested that over-activated microglia cells can release over-production of $\mathrm{NO}$, which can induce neurotoxic injury to neurons and contribute to neurodegenerative diseases [3,34]. In this study, ZB5-1 had the ability to down-regulate the production of NO (Figure 3). Furthermore, it also inhibited LPS-induced iNOS protein levels in a dose-dependent manner (Figure 4A). IL-1 is one of the major pro-inflammatory cytokines produced by activated BV-2 cells, and its over-production has a relationship with neuronal cell damage and many neurodegenerative diseases. Thus, inhibition of IL-1 $\beta$ production serves as a key mechanism in the control of CNS inflammation [35]. This study showed that ZB5-1 inhibited the secretion of IL-1 $\beta$ (Figure 5). Furthermore, we also investigated the inhibitory effect of ZB5-1 on the expression of COX-2, a key enzyme responsible for the conversion of arachidonic acid into prostaglandin $\mathrm{E}_{2}\left(\mathrm{PGE}_{2}\right)$ [36]. Previous studies showed that the expression of COX-2 was elevated during inflammation in neurons and activated microglia cells in brain diseases, such as Alzheimer's disease (AD) and Parkinson's disease (PD) $[37,38]$. Therefore, COX-2 has been deemed to be a target for anti-inflammatory drugs. Several epidemiological studies indicated that treatment with NSAIDs (nonsteroidal anti-inflammatory drugs) can reduce the risk of AD because NSAIDs can delay its onset or slow its progression $[39,40]$. In addition, treatment with COX-2 inhibitors could reduce the inflammatory reaction and increase survival of neurons, decreasing the level of $\mathrm{PGE}_{2}$ [41].

NF- $\mathrm{KB}$ plays a crucial role in host immunity and is a central regulator of microglial responses to stimuli, including LPS and cytokines [42], and its activation in microglia contributes to neuronal injury and promotes the development of neurodegenerative disorders. In addition, ZB5-1 was able to inhibit the phosphorylation of $p 65$, the degradation of $\operatorname{I} \kappa \mathrm{B} \alpha$, and the nuclear translocation of $\mathrm{p} 65$ in LPS-induced BV-2 cells.

Docking is a powerful and theoretical method for the discovery of interactions between molecules and proteins [43]. In our docking studies, a total of 10 random conformations were generated for ZB5-1 in the receptor cavity through high temperature molecular dynamics, preceded by random rotations. In the best molecular interaction pose of ZB5-1 and NF-KB (CDOCKER energy of $-110.64 \mathrm{kcal} / \mathrm{mol}$ and CDOCKER interaction energy of $-10.78 \mathrm{kcal} / \mathrm{mol}$ ), two hydrogen bonds were formed with ASP136 and GLY134, both of which are amino acid residues of NF-KB. The CDOCKER energy was with high negative values, indicating strong interactions between ZB5-1 and NF- $\mathrm{KB}$ [44]. The energy profile suggests that ZB5-1 formed strong interactions with active site residues of NF- $\mathrm{KB}$ due to hydrogen bonds. This study clearly indicates that ZB5-1 might be a good inhibitor of NF- $\kappa B$ that will not degrade by exposure to LPS stimulation.

Regarding the compound structure, ZB5-1 has a furanone ring system. Also known as butyrolactone or butanolide, ZB5-1 is a widely recognized component of natural products, exhibiting an extensive spectrum of pharmacological activities [45]. Moreover, a quantitative structure-activity relationship (QSAR) analysis assessed that furanone derivatives would be a potential inhibitor of COX-2 [46]. There are two phenolic groups in ZB5-1, and it has been proved that phenolic compounds 
possess good anti-inflammatory effects [47]. In the case of ZB5-1 with COX-2, we observed that its CDOCKER energy is $-0.38 \mathrm{kcal} / \mathrm{mol}$, however, the CDOCKER interaction energy is $43.40 \mathrm{kcal} / \mathrm{mol}$, and it forms only one hydrogen bond with TRP373 of COX-2. Due to its small molecule size, it could be suggested that the compound bioavailability would be high, and that it would have the possibility of passing the blood brain barrier (BBB) to reach microglia cells in the brain [48].

\section{Materials and Methods}

\subsection{Reagents}

Lipopolysaccharide (LPS), 3-(4, 5-dimethylthiazol-2-yl)-2, 5-diphenyl-2Htetrazolium bromide (MTT), and dimethylsulfoxide (DMSO) were purchased from Sigma-Aldrich (St. Louis, MO, USA). The Griess Reagent System was obtained from Promega Corporation (Madison, WI, USA). The commercial-specific complete Dulbecco's Modified Eagle's Medium (DMEM), penicillin, and streptomycin were purchased from GIBCO (Carlsbad, CA, USA). The ECL kit was provided from GE Healthcare. 4',6-diamidino-2-phenylindole (DAPI) was obtained from Solarbio (Beijing, China); primary and secondary antibodies used for western blot were purchased from Santa Cruz Biotechnology Inc (Santa Cruz, CA, USA). The anti-NF-kB p65 antibody was obtain from Proteintech Group (Rosemont, IL, USA); Dylight 488 conjugated Goat Anti-Rabbit IgG secondary antibody was purchased from Abbkine (Redlands, CA, USA). The commercial ELISA kit for detecting IL-1 $\beta$ was obtained from Beyotime Biotechnology (Nanjing, China). Those chemicals not mentioned in present research were of analytic grade.

\subsection{Strain, Fermentation, and Purification}

The producer strain XWC21-10 originated from coral Porites pukoensis in Zhanjiang seawaters of the South China Sea, identified as Aspergillus terreus by ITS rDNA sequencing with Genbank number JQ717327, and deposited in the Guangdong culture collection center with accession number GDMCC No. 60004.

This strain was fermented in $1 \mathrm{~L}$ flasks with the total scale of $40 \mathrm{~L}$ in potato dextrose broth (PDB) medium at $28^{\circ} \mathrm{C}$ and $150 \mathrm{rpm}$ on a shaker for a week. After fermentation, the culture was filtrated to separate broth and mycelia, which were respectively extracted by ethyl acetate and ethyl acetate plus chloroform-methanol $(1: 1, v / v)$ mixture. The two extracts were finally combined and condensed in vacuo to a crude extract $(18.7 \mathrm{~g})$. This extract was separated on a Sephadex LH-20 column eluted by chloroform-methanol $(1: 1, v / v)$ to provide 9 fractions ( $\operatorname{Fr} 1$ to $\operatorname{Fr} 9)$. The $\operatorname{Fr} 7$ was further purified by a Sephadex LH-20 column eluted by methanol and then by preparative RP-18 HPLC eluted with 70:30 methanol-water to yield pure compound ZB 5-1 (17.8 mg).

\subsection{Cell Culture and Cell Viability Assay}

The mouse BV-2 microglia cell were obtained from the Cell Bank of Chinese Academy of Sciences (Shanghai, China). The cells were cultured in DMEM supplemented with 5\% FBS and $1 \%$ of penicillin/streptomycin at $37^{\circ} \mathrm{C}$ in a humidified $5 \% \mathrm{CO}_{2}$ incubator. The cytotoxicity of ZB5-1 on BV-2 cells were measured by MTT assay as previously described [49]. Briefly, BV-2 cells were seeded at density $1 \times 10^{4}$ cells $/ \mathrm{mL}$ in 96-well plates and were treated with ZB5-1 (10, 20, 50, $\left.100 \mu \mathrm{M}\right)$ for $24 \mathrm{~h}$. Then $100 \mu \mathrm{L}$ MTT $(1 \mathrm{mg} / \mathrm{mL})$ was added into the cell culture. Four hours later, the formazan crystals were dissolved in DMSO and the absorbance at $540 \mathrm{~nm}$ were investigated using a microplate reader (BioTek, Winooski, VT, USA). The results were expressed as a percentage of surviving cells over control cells.

\subsection{Nitric Oxide Determination}

To examine the inhibitory effect of ZB5-1 on the production of NO, BV-2 cells were seeded at density $5 \times 10^{4}$ cells/well in 96-well plates. The cells were pre-treated with ZB5-1 (10, 20, 50, 
and $100 \mu \mathrm{M})$ for $1 \mathrm{~h}$. They were then activated by LPS $(1 \mu \mathrm{g} / \mathrm{mL})$ for $24 \mathrm{~h}$. The productions of NO were measured using the Griess Reagent System according to previous study [50] protocol.

\subsection{Cytokine Assay}

The level of IL-1 $\beta$ was determined by ELISA as previously described [51]. In brief, BV-2 cells were seeded at $5 \times 105$ cells $/ \mathrm{mL}$ in 24-well plates for $24 \mathrm{~h}$. The cells were pre-treated with ZB5-1 (10, 20, 50 , and $100 \mu \mathrm{M})$ for $1 \mathrm{~h}$ and then activated by LPS $(1 \mu \mathrm{g} / \mathrm{mL})$ for another $24 \mathrm{~h}$. The culture medium was collected and centrifuged at 12,000 rpm for $10 \mathrm{~min}$. The level of IL-1 $\beta$ in the culture medium was quantified using ELISA kits (Beyotime Biotechnology, Shanghai, China).

\subsection{Western Blot Analysis}

Whole cell protein extraction and western blotting were performed as previously described [44]. BV-2 cells were seeded at $5 \times 10^{6}$ cells $/ \mathrm{mL}$ in 6-well plates for $24 \mathrm{~h}$. The cells were pre-treated with ZB5-1 (10, 50, and $100 \mu \mathrm{M})$ for $1 \mathrm{~h}$ and then activated by LPS $(1 \mu \mathrm{g} / \mathrm{mL})$ for another $24 \mathrm{~h}$. The collected cells were rinsed three times with cold phosphate buffer saline (PBS), and total cell lysates were obtained by adding $100 \mu \mathrm{L}$ of RIPA buffer. Protein concentrations were determined using a Pierce BCA Protein Assay Kit (Thermo Fisher Scientific). Equal amounts of protein (20-40 $\mu \mathrm{g})$ were separated electrophoretically using a 10\% sodium dodecyl sulfate-polyacrylamide gel electrophoresis (SDS-PAGE), and the proteins were transferred onto nitrocellulose (NC) membranes (Amersham). Membranes were then blocked with 5\% skim milk and incubated with the primary antibody and the horseradish peroxidase (HRP)-conjugated secondary antibody. Blots were quantified by an Amersham ECL Western Blotting Detection Kit (GE Healthcare).

\subsection{Immunocytochemistry}

Immunocytochemistry was employed to investigate the translation of NF- $\mathrm{kB}$ p65 [51]. BV-2 cells were seeded at $5 \times 10^{4}$ cells $/ \mathrm{mL}$ in 24-well plates for $24 \mathrm{~h}$. The cells were pre-treated with ZB5-1 $(100 \mu \mathrm{M})$ for $1 \mathrm{~h}$ and then activated by LPS $(1 \mu \mathrm{g} / \mathrm{mL})$. After a $24 \mathrm{~h}$ exposure period, cells were washed three times with cold PBS $(0.1 \mathrm{M})$ and were fixed for $10 \mathrm{~min}$ in $4{ }^{\circ} \mathrm{C}$ with ice cold $4 \%$ paraformaldehyde (PFD). Cells were then washed with PBS $(0.1 \mathrm{M})$ and permeabilized with $0.2 \%$ Triton X-100 for $10 \mathrm{~min}$ in $4{ }^{\circ} \mathrm{C}$. The cells were blocked with $5 \%$ bovine serum albumin (BSA) for $1 \mathrm{~h}$ at room temperature (RT). The plates were then incubated overnight at $4{ }^{\circ} \mathrm{C}$ with anti-NF- $\mathrm{kB}$ p65 (rabbit monoclonal IgG, 1:100 dilution). After removing the primary antibody, the cells were washed again and incubated with Dylight 488 conjugated Goat Anti-Rabbit IgG secondary antibody (1:500 dilution) for $2 \mathrm{~h}$ at room temperature $\left(25^{\circ} \mathrm{C}\right)$. Finally, cells were counterstained for $5 \mathrm{~min}$ with $5.0 \mu \mathrm{g} / \mathrm{mL}$ DAPI and washed with PBS. Images were taken using an inverted fluorescence microscope with the imaging software Cell Sens (Olympus Opticals, Tokyo, Japan).

\subsection{Molecular Docking}

Molecular docking between ZB5-1 and NF-kB along with COX-2 was performed by Discovery Studio 3.5 (Accelrys, San Diego, CA, USA). The crystal structures of NF-KB (PDB ID: 1IKN) and COX-2 (3LN1) were obtained from the PDB database. The structure of ZB5-1 was drawn with Chemdraw. The protein and ligand molecules were prepared by DS 3.5 before docking. Molecular docking of the ZB5-1 into the NF- $\mathrm{KB}$ and COX-2 proteins binding sites were performed using CDOCKER protocol. The negative CDOCKER energy was calculated after conducting the molecular docking [52].

\subsection{Statistics}

For the statistical analyses, values are expressed as the means $\pm \operatorname{SD}(n=3)$. The statistical significance was determined by one-way ANOVA and $t$-test. A value of $p<0.05$ was considered statistically significant. 


\section{Conclusions}

In conclusion, our results reveal that ZB5-1 has an anti-neuroinflammatory effect on LPS-induced BV-2 cells. Our results indicated that ZB5-1 significantly reduced LPS-induced NO production in BV2 microglia cells and also inhibited the expression of iNOS and COX-2. Additionally, ZB5-1 suppressed LPS-induced phosphorylation and nuclear translocation of NF- $\mathrm{kB}$ in BV2 microglia cells. Docking study showed that molecular events occurred at the binding interface of ZB5-1 with NF- $\mathrm{kB}$ and COX-2 interaction sites. Therefore, our results suggest that ZB5-1 may act as a potential candidate for treating inflammation-related neurological disorders and provide a new insight into the secondary metabolism derived from marine fungi.

Author Contributions: Y.Y.Z. and Y.Z. acquired, analyzed the data; Y.-B.Y. interpreted and performed statistical analysis; X.-L.L. and Z.-J.Q. conceived and designed the study. All authors drafted the manuscript.

Acknowledgments: The study was supported by the Yangfan Scarce Top Talent Project of Guangdong Province and the Program for Scientific Research Start-up Funds of Guangdong Ocean University (201433008 and 201433009); And supported by Basic Research and Free Exploration Grant of Shenzhen Science and Technology Innovative Committee (JCYJ 20170306165013264) and Department of Science and Technology of Guangdong Province (2013B02100015).

Conflicts of Interest: The authors declare no conflicts of interest.

\section{References}

1. Perry, V.H.; Teeling, J. Microglia and macrophages of the central nervous system: The contribution of microglia priming and systemic inflammation to chronic neurodegeneration. Semin. Immunopathol. 2013, 35, 601-612. [CrossRef] [PubMed]

2. Mandrekar-Colucci, S.; Landreth, G.E. Microglia and Inflammation in Alzheimers Disease. CNS Neurol. Disord. Drug Targets 2010, 9, 156-167. [CrossRef] [PubMed]

3. Cobourne-Duval, M.K.; Taka, E.; Mendonca, P.; Bauer, D.; Soliman, K.F.A. The Antioxidant Effects of Thymoquinone in Activated BV-2 Murine Microglial Cells. Neurochem. Res. 2016, 41, 3227-3238. [CrossRef] [PubMed]

4. Wu, W.Y.; Wu, Y.Y.; Huang, H.; He, C.; Li, W.Z.; Wang, H.L.; Chen, H.Q.; Yin, Y.Y. Biochanin A attenuates LPS-induced pro-inflammatory responses and inhibits the activation of the MAPK pathway in BV2 microglial cells. Int. J. Mol. Med. 2015, 35, 391-398. [CrossRef] [PubMed]

5. Schueffler, A.; Anke, T. Fungal natural products in research and development. Nat. Prod. Rep. 2014, 31, 1425-1448. [CrossRef] [PubMed]

6. Imhoff, J. Natural Products from Marine Fungi-Still an Underrepresented Resource. Mar. Drugs 2016, 14, 19. [CrossRef] [PubMed]

7. Sun, Y.; Liu, J.; Li, L.; Gong, C.; Wang, S.; Yang, F.; Hua, H.; Lin, H. New butenolide derivatives from the marine sponge-derived fungus Aspergillus terreus. Bioorg. Med. Chem. Lett. 2018, 28, 315-318. [CrossRef] [PubMed]

8. Boruta, T.; Bizukojc, M. Production of lovastatin and itaconic acid by Aspergillus terreus: A comparative perspective. World J. Microbiol. Biotechnol. 2017, 33. [CrossRef] [PubMed]

9. Li, H.; Gao, T.; Wang, J.; Tian, S.; Yuan, X.; Zhu, H. Structural identification and antitumor activity of the extracellular polysaccharide from Aspergillus terreus. Process Biochem. 2016, 51, 1714-1720. [CrossRef]

10. Chaiyosang, B.; Kanokmedhakul, K.; Boonmak, J.; Youngme, S.; Kukongviriyapan, V.; Soytong, K.; Kanokmedhakul, S. A new lumazine peptide penilumamide E from the fungus Aspergillus terreus. Nat. Prod. Res. 2016, 30, 1017-1024. [CrossRef] [PubMed]

11. You, M.; Liao, L.; Hong, S.; Park, W.; Kwon, D.; Lee, J.; Noh, M.; Oh, D.-C.; Oh, K.B.; Shin, J. Lumazine Peptides from the Marine-Derived Fungus Aspergillus terreus. Mar. Drugs 2015, 13, 1290-1303. [CrossRef] [PubMed]

12. Da Silva, I.P.; Brissow, E.; Kellner Filho, L.C.; Senabio, J.; de Siqueira, K.A.; Vandresen Filho, S.; Damasceno, J.L.; Mendes, S.A.; Tavares, D.C.; Magalhães, L.G.; et al. Bioactive compounds of Aspergillus terreus_-f7, an endophytic fungus from Hyptis suaveolens (L.) Poit. World J. Microbiol. Biotechnol. 2017, 33. [CrossRef] [PubMed] 
13. Goutam, J.; Sharma, G.; Tiwari, V.K.; Mishra, A.; Kharwar, R.N.; Ramaraj, V.; Koch, B. Isolation and Characterization of "Terrein" an Antimicrobial and Antitumor Compound from Endophytic Fungus Aspergillus terreus (JAS-2) Associated from Achyranthus aspera Varanasi, India. Front. Microbiol. 2017, 8. [CrossRef] [PubMed]

14. Ibrahim, S.R.M.; Mohamed, G.A.; Ross, S.A. Aspernolides L and M, new butyrolactones from the endophytic fungus Aspergillus versicolor. Z. Naturforsch. C 2017, 72, 155-160. [CrossRef] [PubMed]

15. Ibrahim, S.R.M.; Elkhayat, E.S.; Mohamed, G.A.; Khedr, A.I.M.; Fouad, M.A.; Kotb, M.H.R.; Ross, S.A. Aspernolides F and G, new butyrolactones from the endophytic fungus Aspergillus terreus. Phytochem. Lett. 2015, 14, 84-90. [CrossRef]

16. Qi, C.; Bao, J.; Wang, J.; Zhu, H.; Xue, Y.; Wang, X.; Li, H.; Sun, W.; Gao, W.; Lai, Y.; et al. Asperterpenes $\mathrm{A}$ and $\mathrm{B}$, two unprecedented meroterpenoids from Aspergillus terreus with BACE1 inhibitory activities. Chem. Sci. 2016, 7, 6563-6572. [CrossRef] [PubMed]

17. Li, J.; Zhong, M.; Lei, X.; Xiao, S.; Li, Z. Diversity and antibacterial activities of culturable fungi associated with coral Porites pukoensis. World J. Microbiol. Biotechnol. 2014, 30, 2551-2558. [CrossRef] [PubMed]

18. Liu, M.T.; Zhou, Q.; Wang, J.P.; Liu, J.J.; Qi, C.X.; Lai, Y.J.; Zhu, H.C.; Xue, Y.B.; Hu, Z.X.; Zhang, Y.Z. Anti-inflammatory butenolide derivatives from the coral-derived fungus Aspergillus terreus and structure revisions of aspernolides D and G, butyrolactone VI and $4^{\prime}, 8^{\prime \prime}$-diacetoxy butyrolactone VI. RSC Adv. 2018, 8, 13040-13047. [CrossRef]

19. Guo, F.; Li, Z.; Xu, X.; Wang, K.; Shao, M.; Zhao, F.; Wang, H.; Hua, H.; Pei, Y.; Bai, J. Butenolide derivatives from the plant endophytic fungus Aspergillus terreus. Fitoterapia 2016, 113, 44-50. [CrossRef] [PubMed]

20. Liu, Z.; Liu, H.; Chen, Y.; She, Z. A new anti-inflammatory meroterpenoid from the fungus Aspergillus terreus H010. Nat. Prod. Res. 2017, 1-5. [CrossRef] [PubMed]

21. Ye, Y.Q.; Xia, C.F.; Yang, J.X.; Yang, Y.C.; Qin, Y.; Gao, X.-M.; Du, G.; Li, X.-M.; Hu, Q.-F. Butyrolactones Derivatives from the Fermentation Products of an Endophytic Fungus Aspergillus versicolor. Bull. Korean Chem. Soc. 2014, 35, 3059-3062. [CrossRef]

22. Ibrahim, S.R.M.; Asfour, H.Z. Bioactive $\gamma$-butyrolactones from Endophytic Fungus Aspergillus versicolor. Int. J. Pharmacol. 2018, 14, 437-443. [CrossRef]

23. Kiriyama, N.; Nitta, K.; Sakaguchi, Y. Studies on the metabolic products of Aspergillus terreus. III. metabolites of the stain IFO 8835. Chem. Pharma. Bull. 1977, 25, 2593-2601. [CrossRef]

24. Niu, X.; Dahse, H.-M.; Menzel, K.-D.; Lozach, O.; Walther, G.; Meijer, L.; Grabley, S.; Sattler, I. Butyrolactone I Derivatives from Aspergillus terreus Carrying an Unusual Sulfate Moiety. J. Nat. Prod. 2008, 71, 689-692. [CrossRef] [PubMed]

25. Inokoshi, J.; Katagiri, M.; Arima, S.; Tanaka, H.; Hayashi, M.; Bae Kim, Y.; Furumai, R.; Yoshida, M.; Horinouchi, S.; Ōmura, S. Neuronal Differentiation of Neuro 2a Cells by Inhibitors of Cell Cycle Progression, Trichostatin A and Butyrolactone I. Biochem. Biophys. Res. Commun. 1999, 256, 372-376. [CrossRef] [PubMed]

26. Lu, Y.; Takebe, H.; Yagi, T. Inhibition of X-ray and Doxorubicin-induced Apoptosis by Butyrolactone I, a CDK-specific Inhibitor, in Human Tumor Cells. J. Radiat. Res. 2000, 41, 341-348. [CrossRef] [PubMed]

27. Messeha, S.S.; Zarmouh, N.O.; Mendonca, P.; Kolta, M.G.; Soliman, K.F.A. The attenuating effects of plumbagin on pro-inflammatory cytokine expression in LPS-activated BV-2 microglial cells. J. Neuroimmunol. 2017, 313, 129-137. [CrossRef] [PubMed]

28. Wood, L.B.; Winslow, A.R.; Proctor, E.A.; McGuone, D.; Mordes, D.A.; Frosch, M.P.; Hyman, B.T.; Lauffenburger, D.A.; Haigis, K.M. Identification of neurotoxic cytokines by profiling Alzheimer's disease tissues and neuron culture viability screening. Sci. Rep. 2015, 5. [CrossRef] [PubMed]

29. Hwang, J.H.; Wu, S.J.; Wu, P.-L.; Shih, Y.Y.; Chan, Y.-C. Neuroprotective effect of tempeh against lipopolysaccharide-induced damage in BV-2 microglial cells. Nutr. Neurosci. 2018, 1-10. [CrossRef] [PubMed]

30. Whiteman, M. Hydrogen sulfide and nitric oxide interactions in inflammation. Free Radic. Biol. Med. 2011, 51, S10. [CrossRef]

31. Laroux, F.S.; Pavlick, K.P.; Hines, I.N.; Kawachi, S.; Harada, H.; Bharwani, S.; Hoffman, J.M.; Grisham, M.B. Role of nitric oxide in inflammation. Acta Physiol. Scand. 2001, 173, 113-118. [CrossRef] [PubMed]

32. Nagy, G.; Clark, J.M.; Buzás, E.I.; Gorman, C.L.; Cope, A.P. Nitric oxide, chronic inflammation and autoimmunity. Immunol. Lett. 2007, 111, 1-5. [CrossRef] [PubMed] 
33. Tripathi, P.; Tripathi, P.; Kashyap, L.; Singh, V. The role of nitric oxide in inflammatory reactions: Nitric oxide: Control of immune response. FEMS Immunol. Med. Microbiol. 2007, 51, 443-452. [CrossRef] [PubMed]

34. Virarkar, M.; Alappat, L.; Bradford, P.G.; Awad, A.B. L-Arginine and Nitric Oxide in CNS Function and Neurodegenerative Diseases. Crit. Rev. Food Sci. Nutr. 2013, 53, 1157-1167. [CrossRef] [PubMed]

35. Kwon, S.H.; Ma, S.X.; Ko, Y.H.; Seo, J.Y.; Lee, B.R.; Lee, T.H.; Kim, S.Y.; Lee, S.Y.; Jang, C.G. Vaccinium bracteatum Thunb. Exerts Anti-Inflammatory Activity by Inhibiting NF- $k B$ Activation in BV-2 Microglial Cells. Biomol. Ther. 2016, 24, 543-551. [CrossRef] [PubMed]

36. Sil, S.; Ghosh, T. Role of cox-2 mediated neuroinflammation on the neurodegeneration and cognitive impairments in colchicine induced rat model of Alzheimer's Disease. J. Neuroimmunol. 2016, 291, 115-124. [CrossRef] [PubMed]

37. Wang, P.; Guan, P.-P.; Wang, T.; Yu, X.; Guo, J.-J.; Wang, Z.-Y. Aggravation of Alzheimer's disease due to the COX-2-mediated reciprocal regulation of IL-1 $\beta$ and A $\beta$ between glial and neuron cells. Aging Cell 2014, 13, 605-615. [CrossRef] [PubMed]

38. Teismann, P. COX-2 in the neurodegenerative process of Parkinson's disease. BioFactors 2012, 38, 395-397. [CrossRef] [PubMed]

39. Wallace, J.L. COX-2: A Pivotal Enzyme in Mucosal Protection and Resolution of Inflammation. Sci. World J. 2006, 6, 577-588. [CrossRef] [PubMed]

40. Rajakariar, R.; Yaqoob, M.M.; Gilroy, D.W. COX-2 in inflammation and resolution. Mol. Interv. 2006, 6, 199-207. [CrossRef] [PubMed]

41. Giovannini, M.G.; Scali, C.; Prosperi, C.; Bellucci, A.; Pepeu, G.; Casamenti, F. Experimental brain inflammation and neurodegeneration as model of Alzheimer's disease: Protective effects of selective cox-2 inhibitors. Int. J. Immunopathol. Pharm. 2003, 16, 31-40.

42. Jawan, B.; Kao, Y.; Goto, S.; Pan, M.; Lin, Y.; Hsu, L.; Nakano, T.; Lai, C.; Sun, C.; Cheng, Y. Propofol pretreatment attenuates LPS-induced granulocyte-Macrophage colony-stimulating factor production in cultured hepatocytes by suppressing MAPK/ERK activity and NF-kB translocation. Toxicol. Appl. Pharmacol. 2008, 229, 362-373. [CrossRef] [PubMed]

43. Chopra, D.; Ray, L.; Dwivedi, A.; Tiwari, S.K.; Singh, J.; Singh, K.P.; Kushwaha, H.N.; Jahan, S.; Pandey, A.; Gupta, S.K.; et al. Photoprotective efficiency of PLGA-curcumin nanoparticles versus curcumin through the involvement of ERK/AKT pathway under ambient UV-R exposure in HaCaT cell line. Biomaterials 2016, 84, 25-41. [CrossRef] [PubMed]

44. Verma, A.; Kushwaha, H.N.; Srivastava, A.K.; Srivastava, S.; Jamal, N.; Srivastava, K.; Ray, R.S. Piperine attenuates UV-R induced cell damage in human keratinocytes via NF-kB, Bax/Bcl-2 pathway: An application for photoprotection. J. Photochem. Photobiol. B 2017, 172, 139-148. [CrossRef] [PubMed]

45. Ngwane, A.H.; Panayides, J.L.; Chouteau, F.; Macingwana, L.; Viljoen, A.; Baker, B.; Madikane, E.; de Kock, C.; Wiesner, L.; Chibale, K.; et al. Design, synthesis, and In vitro antituberculosis activity of 2(5 H)-Furanone derivatives: In Vitro Anti-TB Activity of Synthetic Furanones. IUBMB Life 2016, 68, 612-620. [CrossRef] [PubMed]

46. Bhatiya, R.; Vaidya, A.; Kashaw, S.K.; Jain, A.K.; Agrawal, R.K. QSAR analysis of furanone derivatives as potential COX-2 inhibitors: KNN MFA approach. J. Saudi Chem. Soc. 2014, 18, 977-984. [CrossRef]

47. Amir, M.; Javed, S.A.; Kumar, H. Synthesis of Some Newer Analogues of 4-Hydroxyphenyl Acetic Acid as Potent Anti-Inflammatory Agents. J. Chin. Chem. Soc. 2008, 55, 201-208. [CrossRef]

48. Himaya, S.W.A.; Ryu, B.; Qian, Z.J.; Li, Y.; Kim, S.-K. 1-(5-bromo-2-hydroxy-4-methoxyphenyl) ethanone [SE1] suppresses pro-inflammatory responses by blocking NF- $\mathrm{kB}$ and MAPK signaling pathways in activated microglia. Eur. J. Pharmacol. 2011, 670, 608-616. [CrossRef] [PubMed]

49. Qian, Z.J.; Kang, K.H.; Kim, S.K. Isolation and antioxidant activity evaluation of two new phthalate derivatives from seahorse, Hippocampus Kuda Bleeler. Biotechnol. Bioprocess Eng. 2012, 17, 1031-1040. [CrossRef]

50. Ryu, B.; Qian, Z.J.; Kim, S.K. SHP-1, a novel peptide isolated from seahorse inhibits collagen release through the suppression of collagenases 1 and 3, nitric oxide products regulated by NF-кB/p38 kinase. Peptides 2010, 31, 79-87. [CrossRef] [PubMed] 
51. Zhao, D.; Kwon, S.-H.; Chun, Y.S.; Gu, M.Y.; Yang, H.O. Anti-Neuroinflammatory Effects of Fucoxanthin via Inhibition of Akt/NF-kB and MAPKs/AP-1 Pathways and Activation of PKA/CREB Pathway in Lipopolysaccharide-Activated BV-2 Microglial Cells. Neurochem. Res. 2017, 42, 667-677. [CrossRef] [PubMed]

52. Wu, G.; Robertson, D.H.; Brooks, C.L.; Vieth, M. Detailed analysis of grid-based molecular docking: A case study of CDOCKER A CHARMm-based MD docking algorithm. J. Comput. Chem. 2003, 24, 1549-1562. [CrossRef] [PubMed]

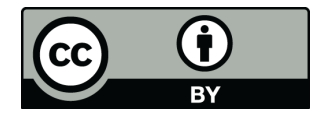

(C) 2018 by the authors. Licensee MDPI, Basel, Switzerland. This article is an open access article distributed under the terms and conditions of the Creative Commons Attribution (CC BY) license (http:/ / creativecommons.org/licenses/by/4.0/). 